\title{
Joanna Hajduga
}

The "Be not afraid!" John Paul II Centre, Poland

\section{The "Be not afraid!" John Paul II Centre www.janpawel2.pl www.facebook.com/centrumjp2}

"May Krakow's John Paul II Centre be a place of faith, cultivation and merciful love. May it strengthen unity between people and nations. May the spirit of John Paul II prevail the Centre: the spirit of respect towards humanity, the spirit of openness and of determination in building a civilisation of love, and in shaping sensitivity and a vision of mercy".

Cardinal Stanisław Dziwisz, Metropolitan Archbishop of Krakow

The "Be not afraid!" John Paul II Centre was established by Cardinal Stanisław Dziwisz on January $2^{\text {nd }} 2006$ as a response on the part of the Church in Krakow to the words spoken by the Holy Father, of happy memory, on the $22^{\text {nd }}$ October of 1978, which was the inauguration day of his Pontificate: “(...) Be not afraid! Open wide the doors for Christ! To his saving power open the boundaries of States, economic and political systems, the vast fields of culture, civilisation and development. Be not afraid! (...)".

The Centre is a continuation of the work inaugurated by the John Paul II Institute, which was founded on the initiative of Cardinal Priest Franciszek Macharski for the purpose of increasing the knowledge of both the person and the teaching of Cardinal Karol Wojtyła, professor of ethics and shepherd of the Archdiocese of Krakow. 


\section{A Centre of 'living memory'}

Blessed John Paul II is a priceless and binding gift to the contemporary Church. The testimony to his faith and teachings is a spiritual programme and his bequest to us, his generation and the generations thatare to come.

The mission of The "Be Not Afraid!" John Paul II Centre is to create a living memory of the person and works of our Great Compatriot.

The Centre guards, preserves and intensifies the papal legacy in order that we may draw upon its rich treasure of thoughts, reflections, deliberations, prayers and attitudes, as well as to promote the values by which the Blessed John Paul II lived and which he taught.

The John Paul II Prayer School and the Sursum Corda New Evangelisation School are run under the auspices of the Centre, which is also home to the John Paul II Institute of Intercultural Dialogue in Krakow and the Non-Public InService Teacher Training Centre.

\section{You are most cordially invited to the Sanctuary of the Blessed John Paul II}

The "Be not afraid!" John Paul II Centre warmly invites you to the Sanctuary of the Blessed John Paul II, which was formally opened in a ceremony conducted by the Metropolitan Archbishop of Krakow, Cardinal Stanisław Dziwisz, on 11 June 2011.

Holy Mass is celebrated on weekdays, Sundays and Holy Days at 8.00 AM, 10.00 AM, 11.15 AM, 12.30 PM and 5.00 PM.

\section{Building the House of John Paul II}

"A symbol of our memory of John Paul II will be born of this work, a symbol which will endure for generation upon generation" (Cardinal Stanisław Dziwisz).

On October $11^{\text {th }}$ 2008, Cardinal Stanisław Dziwisz ceremonially inaugurated the construction of The "Be not afraid!" John Paul II Centre. In order to preserve spiritual unity with the Blessed John Paul II and commemorate the Polish Pope's legacy in Krakow, the following buildings will be erected:

Phase One:

- the Sanctuary of the Blessed John Paul II 
- the Volunteer Centre

- the John Paul II Institute.

Subsequent phases encompass:

- a multimedia museum devoted to the life and works of the Polish Pope

- a retreat

- a conference centre

- a Pilgrims' House

- a rehabilitation centre

- a meditation and recreation park.

On October $23^{\text {rd }} 2010$, the cornerstone of the future Centre, blessed by Pope Benedict XVI during his first pilgrimage to Poland, was set into the foundations of the church that will stand where sodium works once stood. 